OPEN ACCESS

Edited by:

Rachel R. Caspi,

National Institutes of Health (NIH),

United States

Reviewed by:

Megan K. Levings,

University of British Columbia, Canada

Irun R. Cohen,

Weizmann Institute of Science, Israel

*Correspondence:

Jude E. Uzonna

jude.uzonna@umanitoba.ca

Specialty section:

This article was submitted to

Immunological Tolerance and

Regulation,

a section of the journal

Frontiers in Immunology

Received: 05 November 2018 Accepted: 12 March 2019

Published: 09 April 2019

Citation:

Okeke EB and Uzonna JE (2019) The

Pivotal Role of Regulatory T Cells in

the Regulation of Innate Immune Cells.

Front. Immunol. 10:680.

doi: $10.3389 /$ fimmu.2019.00680

\section{The Pivotal Role of Regulatory T Cells in the Regulation of Innate Immune Cells}

\author{
Emeka B. Okeke ${ }^{1}$ and Jude E. Uzonna ${ }^{2 *}$ \\ ${ }^{1}$ Department of Pharmaceutical Sciences, University of Michigan, Ann Arbor, MI, United States, ${ }^{2}$ Department of Immunology, \\ Faculty of Medicine, University of Manitoba, Winnipeg, MB, Canada
}

The distinction between innate and adaptive immunity is one of the basic tenets of immunology. The co-operation between these two arms of the immune system is a major determinant of the resistance or susceptibility of the host following pathogen invasion. Hence, this interactive co-operation between cells of the innate and adaptive immunity is of significant interest to immunologists. The sub-population of CD4 ${ }^{+} \mathrm{T}$ cells with regulatory phenotype (regulatory $T$ cells; Tregs), which constitute a part of the adaptive immune system, have been widely implicated in the regulation of the immune system and maintenance of immune homeostasis. In the last two decades, there has been an explosion in research describing the role of Tregs and their relevance in several immunopathologies ranging from inflammation to cancer. The majority of these studies focus on the role of Tregs on the cells of the adaptive immune system. Recently, there is significant interest in the role of Tregs on cells of the innate immune system. In this review, we examine the literature on the role of Tregs in immunology. Specifically, we focus on the emerging knowledge of Treg interaction with dendritic cells, macrophages, neutrophils, and $\gamma \delta \mathrm{T}$ cells. We highlight this interaction as an important link between innate and adaptive immune systems which also indicate the far-reaching role of Tregs in the regulation of immune responses and maintenance of self-tolerance and immune homeostasis.

\footnotetext{
Keywords: cytokines, dendritic cells, neutrophils, inflammation, lymphocyte, homeostasis, immune tolerance, monocytes/macrophages
}

\section{INTRODUCTION}

The immune system protects the host against pathogen invasion and is therefore armed with an arsenal of deadly ammunition (cells and proteins) necessary for the elimination of microbes or substances determined to pose significant threat to the normal functioning of the host. This inherent function made it imperative that the evolution of host immunity encompasses important mechanisms to prohibit the destruction of self. Hence, the maintenance of immune tolerance is central to the normal functioning of the immune system and breakdown of immune tolerance results in catastrophic consequences to the host.

Increase in knowledge of the immune system has greatly helped to delineate the important mechanisms involved in maintenance of immune tolerance. It is now known that a core aspect of lymphocyte development is the elimination of lymphocytes that are reactive to self-ligands by the process of negative selection (1). It seems pertinent that the immune system develop fail-safe 
mechanisms to handle self-reactive lymphocytes that were not eliminated during the process of negative selection. One such mechanism that has been proposed for decades is the ability of a subtype of $\mathrm{T}$ lymphocytes to suppress the function of other lymphocytes. This sub-population of $\mathrm{T}$ lymphocytes identified by the expression of CD4, CD25, and FOXP3 has been shown to be a major player in the maintenance of immune tolerance and homeostasis $(2,3)$. These naturally occurring regulatory $\mathrm{T}$ cells (Tregs) comprise $5-10 \%$ of peripheral $\mathrm{CD}^{+} \mathrm{T}$ cells in the circulation, have potent suppressive abilities and were initially known to suppress $\mathrm{CD} 4{ }^{+} \mathrm{CD} 25^{-} \mathrm{T}$ cells (4). Recently, Tregs have been implicated in the regulation of other cells of the adaptive immune system including $\mathrm{CD} 8^{+} \mathrm{T}$ cells and $\mathrm{B}$ cells (5-7).

It is well-known that the co-operative interaction between cells of the innate immune system and cells of the adaptive immune system is crucial for the induction of adequate immune response. Recent findings that Tregs regulate the function of cells of the innate immune system like macrophages, dendritic cells, and neutrophils are intriguing and indicate the significant overlap between both arms of immunity. In this review, we discuss the essential role of Tregs (defined by the expression of $\mathrm{CD} 4, \mathrm{CD} 25$, and FOXP3) in the maintenance of immune tolerance. In particular, we focus on the emerging role of Tregs as regulators of cells of the innate immune system. We highlight the under-explored interaction between Tregs and cells of the innate immune system and the significance of this interaction in the maintenance of immune tolerance and in the pathogenesis of autoimmune diseases.

\section{REGULATORY T CELLS AND IMMUNITY}

Several lines of evidence summarized in Table 1, led to the development of Treg biology. The history of Tregs, the biological origin and the terms of classification of Treg subtypes have been well-reviewed elsewhere $(3,29,30)$ and highlighted for the reader's information.

It is worthy of note that in addition to the naturally occurring Treg cells, $\mathrm{CD}^{+} \mathrm{T}$ cells with regulatory phenotype can be induced in vivo and in vitro with antigenic stimulation in the presence of IL-10. These so called IL-10-producing T regulatory type 1 ( $\operatorname{Tr} 1)$ cells (31) usually do not express FOXP3 and have been shown to have potent suppressive ability $(21,32)$. Notably, $\mathrm{Tr} 1$ cells are able to inhibit $\mathrm{CD} 4^{+} \mathrm{T}$ cell responses through IL-10 dependent and independent mechanisms (33-37). Importantly, Tr1 cells are distinct from FOXP3 ${ }^{+}$Tregs (natural Tregs) because they do not constitutively express FOXP3. Also, Tr1 cells have been shown to function separately from $\mathrm{FOXP}^{+}$Tregs in certain conditions $(38,39)$. The biology and functional characteristics of $\operatorname{Tr} 1$ cells have been recently reviewed exhaustively $(40,41)$ and these articles are recommended for readers wanting more information on these cells.

Tregs were originally identified as a subset of immune cells critical for the maintenance of self-tolerance and prevention of autoimmune diseases (19). However, since their discovery, Tregs have been ascribed the eminent role of an omnipotent wonder regulatory cell that is paramount in nearly all immunological
TABLE 1 | Summary of findings leading to discovery of Tregs

\begin{tabular}{|c|c|c|}
\hline Year & Discovery & References \\
\hline $\begin{array}{l}1970 \\
1972\end{array}$ & $\begin{array}{l}\text { Ability of thymocytes to induce lymphocyte } \\
\text { Suppression was reported. }\end{array}$ & $(8,9)$ \\
\hline $\begin{array}{l}1972 \\
1973\end{array}$ & $\begin{array}{l}\text { Introduction of the concept of suppressor T cells } \\
\text { (Tsups). }\end{array}$ & $(10-12)$ \\
\hline 1976 & $\begin{array}{l}\text { Identification of the phenotype of Tsups based on } \\
\text { cell surface antigens. }\end{array}$ & $(13,14)$ \\
\hline 1976 & $\begin{array}{l}\text { Report that the I-J region of the MHC is responsible } \\
\text { for Tsups activity. }\end{array}$ & $(15,16)$ \\
\hline $\begin{array}{l}1983 \\
1986\end{array}$ & $\begin{array}{l}\text { RNA and DNA screening fails to identify the I-J } \\
\text { region of the MHC responsible for Tsups activity } \\
\text { leading to the demise of Tsups. }\end{array}$ & $(17,18)$ \\
\hline 1995 & $\begin{array}{l}\text { Identification of } \mathrm{CD}^{+}{ }^{+} \mathrm{CD} 25^{+} \mathrm{T} \text { cells as regulatory } \\
\mathrm{T} \text { cells (Tregs). }\end{array}$ & $(19,20)$ \\
\hline 1997 & Identification of T regulatory type 1 (Tr1) cells. & (21) \\
\hline 1998 & $\begin{array}{l}\mathrm{CD} 4^{+} \mathrm{CD} 25^{+} \text {Tregs shown to be a distinct lineage } \\
\text { of suppressor cells. }\end{array}$ & $(22,23)$ \\
\hline 2001 & $\begin{array}{l}\text { Identification of Tregs function as the cause of } \\
\text { Scurfy and IPEX syndromes in mice and humans, } \\
\text { respectively. }\end{array}$ & $(24,25)$ \\
\hline 2003 & $\begin{array}{l}\text { Identification of the transcription factor forkhead box } \\
\text { P3 (FOXP3) as essential for Treg function. }\end{array}$ & $(26-28)$ \\
\hline
\end{tabular}

responses such as oral tolerance (42), fetal-maternal tolerance (43), infectious tolerance (44), transplantation tolerance (45), allergen-induced hypersensitivities (46), and even immune memory (47).

In their landmark paper, Sakaguchi et al. initially showed that Tregs protect the host from autoimmune diseases (19). They showed that transfer of $\mathrm{CD} 4^{+}$cells depleted of $\mathrm{CD} 25^{+}$ population into athymic syngeneic nude mice resulted in autoimmune pathologies in several organs. Additionally, they demonstrated the significant role of Tregs in maintenance of transplantation tolerance by showing that depletion of Tregs leads to heightened rejection of allogeneic skin grafts (19). Since then, several studies have associated defective Treg function with the development of several autoimmune diseases. In mice, a mutation in the FOXP3 gene leads to a lethal wasting disease characterized by exaggerated $\mathrm{CD}^{+} \mathrm{T}$ cell activity (25). An analogous autoimmune disease in humans known as immune dysregulation, polyendocrinopathy, enteropathy Xlinked (IPEX) syndrome is associated with the dysfunction of FOXP3 gene (24). In animal studies, depletion of Tregs leads to rapid and severe onset of arthritis and adoptive transfer of Tregs rescues the animals from the disease (48). In humans, reduced Treg populations are associated with the exacerbated form of juvenile idiopathic arthritis and rheumatoid arthritis $(49,50)$. Similarly, a mutation in FOXP3 gene is associated with spontaneous development of inflammatory bowel disease (IBD) (26) and a phase 1 clinical trial of Treg therapy in patients with refractory Crohn's disease was found to be effective (51). Also defective Treg function has been implicated in the development of type 1 diabetes (52), multiple sclerosis (53), and atopic dermatitis (54). Indeed, there is overwhelming experimental evidence of the significance of Tregs in the prevention of 
autoimmune diseases and the current challenge is the translation of this knowledge to effective clinical therapy for patients with autoimmune diseases.

The role of Tregs in maintenance of host immunity during infection is controversial. While some studies indicate that the suppressive nature of Tregs limit the immune response to infection and is detrimental to the host, other studies have shown that Tregs are essential for the successful elimination of pathogens and the prevention of pathogeninduced immunopathologies. For example, in the case of sepsis (systemic inflammatory response to infection), Venet et al. showed that increased numbers of Tregs is associated with poor outcome (55). In contrast, Heuer et al. reported that adoptive transfer of in vitro stimulated Tregs increased bacterial clearance and improved survival in murine model of sepsis (56). Also, Cambos et al. showed that Tregs suppress excessive inflammation in lethal plasmodium chabaudi adami infection in which mortality is associated with systemic inflammatory response (57). Tregs have also been shown to be protective in viral infections. Lund et al. demonstrated that Tregs facilitated the recruitment of immune cells for protection against herpes simplex virus in mice (58).

We recently showed that immunological or genetic inhibition of Tregs function by using an anti-CD25 monoclonal antibody (anti-CD25 mAb) treatment or mice lacking functional Tregs (CD25 KO mice), respectively, was detrimental in a sepsis model of bacterial infection or LPS-induced acute inflammatory response (59). This was associated with exaggerated production of pro-inflammatory cytokines including IL- $1 \beta$, IL-6, IL-12, TNF, and CCL2. Strikingly, adoptive transfer of Tregs from wild-type mice into CD25 KO mice before LPS challenge rescues them from an otherwise acute death (59).

The initial work of Sakaguchi et al. indicated that Tregs regulate $\mathrm{CD} 4{ }^{+} \mathrm{CD} 25^{-}$Th cells since their depletion leads to exaggerated $\mathrm{CD}^{+}$Th cell response resulting in immunopathology (19). This role of Tregs in regulating $\mathrm{CD} 4^{+}$ Th cell function has also been reported in several studies $(52,53,60)$. We recently showed that Tregs regulate $\mathrm{CD} 4^{+} \mathrm{Th}$ cells in a murine model of sepsis (61). Following Treg depletion, $\mathrm{CD}^{+}$Th cells exhibit increased cellular activity in response to LPS which leads to exuberant activation of other immune cells such as macrophages resulting in excessive inflammatory response, organ damage, and mortality (61). In addition to regulation of $\mathrm{CD}^{+}$Th cells, Tregs have also been shown to regulate other cells of the adaptive immune system like $\mathrm{CD} 8^{+} \mathrm{T}$ cells and B cells $(5,6)$. However, a limited number of studies have examined the role of Tregs in the regulation of innate immune cells. We will focus on the essential interaction between Tregs and cells of the innate immune system in the maintenance of immune homeostasis in the remainder of this review.

\section{TREGS AND DENDRITIC CELLS}

The role of a specialized group of immune cells, aptly called antigen presenting cells (APCs), in providing the necessary second signal for lymphocyte activation is highly appreciated.
Dendritic cells (DCs) were first identified as Langerhans cells in the skin in 1868 but their primary role in immune response was not recognized until the 1970s (62). Although their primary role in immune response was only recently discovered, DCs are the most potent APCs in vitro and in vivo (63). Currently, DCs are appreciated as the sentinels of the immune system. They are present in tissues and in the peripheral circulation, surveying the host immune system for the presence of antigens and upon antigen encounter rapidly upregulate co-stimulatory molecules and migrate to the lymph node where they present antigens to T cells (63). Additionally, DCs secrete cytokines like IL-12 that can activate T cells. The role of DCs in the immune response has been well-reviewed (63-65), hence we will focus on the crosstalk between DCs and Tregs in the regulation of the immune response.

Paradoxically, DCs that are essential for the activation of the immune response have also been implicated in the induction of immune tolerance. Finkelman et al. showed that DCs can induce both immune activation and immune tolerance. They showed that in the absence of additional stimuli, injection of mice with a rat IgG2b anti-DC mAb leads to $\mathrm{T}$ cell specific tolerance to rat IgG (66). Also, Hawiger et al. showed that targeted delivery of antigen via DC-restricted endocytic receptor, DEC-205, leads to $\mathrm{T}$ cell unresponsiveness or anergy (67). However, in the presence of a second signal such as may be provided by coinjection of anti-CD40 agonistic antibody, immune activation is observed instead of tolerance (67). Hence, DCs can tilt the immune response to tolerance or activation if insufficient signal is received. This is understandable as unwarranted immune activation can result in autoimmune pathologies. It is thought that the induction of tolerance by DCs is dependent on the degree of DC maturation. Immature or semi-mature DCs that encounter antigen that does not result in full maturation induce immune tolerance while full antigenic maturation of DCs leads to immune activation (68).

One way by which DCs help in the maintenance of immune tolerance is by induction of Tregs. Compared to B cells and macrophages, DCs are more efficient in the induction of Tregs (69) and DC-depleted APCs show a significant reduction in the ability to induce Tregs (70). Studies have shown that, double positive thymocytes are selected for commitment to Treg lineage depending on the intensity of their response to selfantigens presented by thymic DCs (71). It appears that the underlying factor which determines Treg induction by DCs is the strength of the antigenic stimuli. For example, Kretschmer et al. demonstrated that subimmunogenic antigen delivery to DCs resulted in the generation of Tregs from naïve $\mathrm{CD} 4^{+} \mathrm{T}$ cells in the periphery (72). This observation is supported by other reports which show that strong activation of DCs leads to production of cytokines which inhibit Treg induction $(73,74)$. Thus, it appears that there is an immunogenic threshold observed by DCs below which DCs help to maintain immune tolerance through the induction of Tregs.

How does DCs promote Treg induction? Studies have shown that DCs promote Treg induction through cytokine and noncytokine mediators. For example, the induction of Tregs by DCs has been shown to be mediated through the inhibitory 
molecule programmed death-ligand 1 (PD-L1) expressed on DCs. Hence, genetic or immunological inhibition of PD-L1 on DCs leads to their inability to induce FOXP3 ${ }^{+}$Tregs even in the presence of the necessary cytokine signals (75). Treg expansion and differentiation by DCs is highly favored in the presence of certain cytokines. In particular, the cytokines IL-10 and TGF- $\beta$ are important in the induction of Tregs by DCs. The regulatory function of IL-10 has been well-studied in the context of several immunopathologies. IL-10 is a potent inhibitor of the immune response (76) and deficiency of IL-10 has been shown to result in exaggerated immune responses to pathogens leading to immunopathology (77-79). Indeed, it is well-established that IL-10 induces the class of $\operatorname{Tr} 1$ cells which are functionally similar to naturally occurring Tregs (32). Importantly, Tr1 cells have been shown to mediate their regulatory function through the production of IL-10 $(38,80,81)$. In vitro, activation of effector T cells (Teff) with IL-10-treated DCs leads to anergy and generation of $\operatorname{Tr} 1$ cells $(31,82,83)$. IL-10-treated DCs have potent suppressive ability and have been shown to be effective in experimental treatment of allergic asthma (84), graftvs.-host disease (85) and inflammatory bowel disease (86). In addition to induction of $\operatorname{Tr} 1$ cells through exogenous IL-10, DCs also induce $\operatorname{Tr} 1$ cells by the secretion of IL-10 $(87,88)$. Hence, there is a positive feedback mechanism by which IL-10 induces tolerogenic DCs which then acquire the ability to secrete IL-10 and in turn induce tolerance through induction of $\operatorname{Tr} 1$ cells. Since Tregs produce IL-10, it follows that Tregs can also induce tolerogenic DCs and this two-way relationship between Tregs and DCs via IL-10 is a critical mechanism of maintaining immune tolerance (Figure 1).

In addition to mediating tolerance through IL-10, DCs have also been shown to mediate tolerance through the immunoregulatory cytokine TGF- $\beta$. The essential role of TGF$\beta$ in the maintenance of immune tolerance has been wellestablished. TGF- $\beta$ is important for the development and function of FOXP3 ${ }^{+} \mathrm{T}$ cells $(89,90)$ and Tregs also mediate tolerance through the secretion of TGF- $\beta$ (91). Mice lacking TGF- $\beta$ signaling develop a fatal lymphoproliferative disease similar to scurfy mice $(92,93)$. Interestingly, DCs have been shown to induce FOXP3 ${ }^{+}$Tregs from FOXP3 ${ }^{-}$precursors in the presence of exogenous and endogenous TGF- $\beta$ (70). Evidence of the role of DCs in the maintenance of immunological tolerance through TGF- $\beta$ is compelling. Laouar et al. demonstrated that targeted functional inactivation of TGF- $\beta$ receptor signaling in DCs resulted in enhanced $\mathrm{T}$ cell responses in experimental autoimmune encephalomyelitis (EAE) (94). Yamazaki et al. showed that $\mathrm{CD} 8^{+} \mathrm{CD} 205^{+}$DCs induce Tregs via the production of TGF- $\beta$ (95). In line with this, antibody neutralization of TGF$\beta$ abrogates the ability of $\mathrm{CD}^{+} \mathrm{CD} 205^{+}$DCs to induce Tregs (95). Travis et al. showed that the induction of Tregs by DCs via TGF- $\beta$ is mediated by the cytokine activating $\alpha_{\mathrm{V}} \beta_{8}$ integrin on DCs (96). They showed that targeted disruption of $\alpha_{\mathrm{v}} \beta_{8}$ on DCs leads to autoimmune disease. In contrast disruption of $\alpha_{v} \beta_{8}$ on $\mathrm{T}$ cells does not lead to autoimmune disease indicating that TGF- $\beta$ signaling through DCs is paramount for the maintenance of immune tolerance. Furthermore, mice with DCs lacking $\alpha_{\mathrm{v}} \beta_{8}$ have reduced Tregs in the colon. Additionally, DCs lacking $\alpha_{v} \beta_{8}$ lose the ability to induce Tregs in vitro (96). On the other hand, Worthington et al. showed that Tregs also express high amounts of $\alpha \mathrm{v} \beta 8$, which enables them to activate latent TGF- $\beta$ for the suppression of $\mathrm{T}$ cell-mediated inflammation (97). In line with this, recent studies show that Tregs mediate their suppressive function by activating latent TGF- $\beta 1$ presented by GARP (glycoprotein A repetitions predominant) to integrin $\alpha \mathrm{V} \beta 8$ on their surface (98-100). Collectively, these studies demonstrate the essential role of TGF- $\beta 1$ in Treg function.

Studies have also shown that DCs produce the vitamin A metabolite-retinoic acid (RA) and that RA-producing DCs are important for Treg induction (101). Interestingly, Tregs can be generated de novo from peripheral $\mathrm{T}$ cells in human or murine blood by RA (102-104). Also incubation of Tregs with TGF- $\beta$ and RA increases their suppressive ability (105). Additionally, intestinal DCs treated with an antagonist against RA receptor lose their ability to induce Tregs (105). The mechanism by which RA leads to the induction of tolerogenic DCs is not completely understood. Studies have shown that RA-producing enzyme retinal dehydrogenase 2 (RALDH2), which is encoded by Aldh1a2 gene, is highly expressed by DCs in mesenteric lymph node (MLN) and peyer's patches compared to DCs from other lymphoid organs $(101,106)$. Recent work by Ohoka et al. showed that RA and granulocyte-macrophage colony-stimulating factor (GM-CSF) induced the expression of Aldh1a2 in DCs through the interaction of RA receptor and retinoid $\mathrm{X}$ receptor complex and subsequent activation of the transcription factor sp1 (107). Indeed, accumulating evidence suggests that RA-producing DCs play an essential role in the maintenance of oral tolerance (108). $\mathrm{T}$ or B cells activated in the presence of RA are "imprinted" to express gut-homing receptors (106). Also, Siewert et al. showed that Tregs preferentially migrate to the gut following treatment with RA (109). It has been proposed that RA produced by DCs increase TGF- $\beta$-dependent induction of Tregs from naïve $T$ cells by inhibiting their differentiation into inflammatory $\mathrm{T}$ cells. In line with this, Balmer and Blomhoff found that RA increases TGF- $\beta$ receptor subunit signaling (110). The role of RA in the maintenance of oral tolerance is understandable since the gut is constantly barraged by exposure to foreign and commensal antigens and maintenance of tolerance without compromising immunity is a priority. Previous studies identified $\mathrm{CD}_{103^{+}} \mathrm{DCs}$ in the gut-associated lymphoid tissue (GALT) as the subset of DCs that produce RA necessary for Treg induction in the gut (105). However, recent findings indicate that RA production by DCs is not restricted to the $\mathrm{CD}_{103}{ }^{+} \mathrm{DCs}$ in the GALT. Guilliams et al. found $\mathrm{CD}_{103^{-}} \mathrm{RA}$-producing DCs in the skin and lung draining lymph nodes (111). These observations highlight the essential role of different subsets of DCs in the maintenance of immune tolerance via production of RA.

\section{TREGS AND MACROPHAGES}

Macrophages have long been appreciated as important immune cells that help to maintain immune homeostasis via phagocytosis of foreign matter, apoptotic or necrotic cells (112). As an important part of the innate immune system, they possess several 


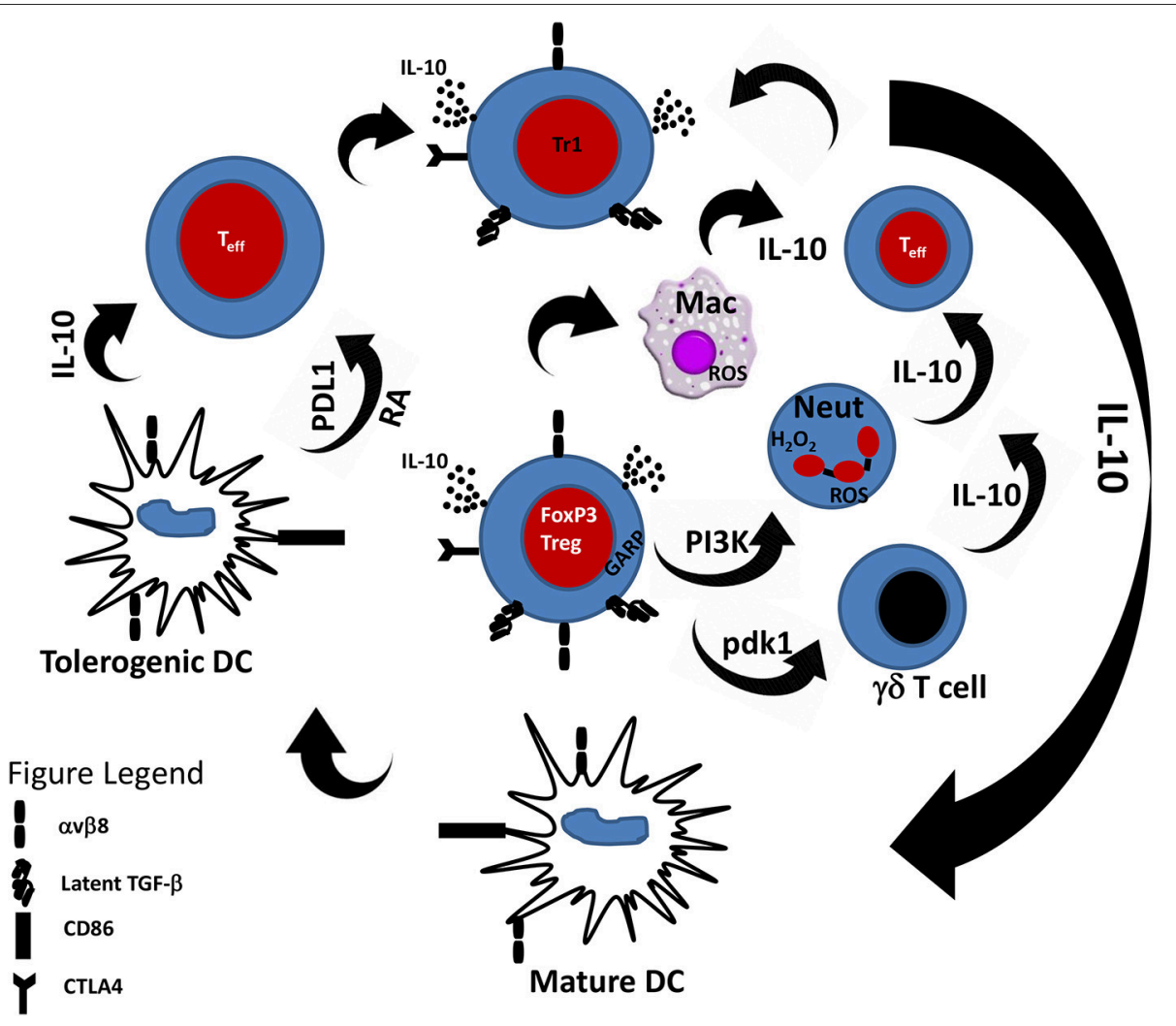

FIGURE 1 | Cross-talk between Tregs and innate immune cells. Tregs through the secretion of IL-10 and TGF- $\beta$ are able to modulate the response of innate immune cells toward an anti-inflammatory phenotype. Likewise, innate immune cells in the presence of IL-10 can induce Tr1 cells that can suppress effector T cell response. PDL1, Programmed death-ligand 1; RA, Retinoic acid.

pathogen recognition receptors (PRRs) and are quickly mobilized to the infection site preceded only by neutrophils. Macrophages play an important role in shaping the adaptive immune response. For example, macrophages present antigens to $\mathrm{T}$ and $\mathrm{B}$ cells and also secrete several cytokines which directs the responses of $\mathrm{T}$ and B cells (113).

It is now well-known that macrophages assume distinct phenotype and function based on their microenvironment. Hence, macrophages are broadly classified into two-the proinflammatory M1 macrophages which arise in the presence of cytokines like IFN- $\gamma$ and IL-12, and the anti-inflammatory M2 macrophages (114). M2 macrophages are further subdivided based on the cytokine signals that give rise to them: M2a (IL4 or IL-13), M2b (IL-1 $\beta$, LPS, and immune complexes), and M2c (IL-10, TGF- $\beta$, or glucocorticoids) (115). Unlike the M1, M2 macrophages especially the M2c subset have a regulatory phenotype (116) and the regulatory role of macrophages have been of significant interest in recent years.

The relationship between Tregs and macrophages and the role of macrophages in the maintenance of immune tolerance has been severely under-explored compared to Treg/DC interaction. However, there is evidence that Treg/macrophage interaction significantly modulates host immune response. For example, coculture of macrophages and Tregs leads to reduced expression of HLA-DR on macrophages and reduced production of proinflammatory cytokines in response to LPS stimulation (117). Recently, our group showed that depletion of Tregs leads to exaggerated macrophage activation that results in mortality to endotoxic shock (61).

Currently, there is significant interest in the role of regulatory macrophages (Mregs) in inflammation and cancer and the crosstalk between Tregs and Mregs. As described above, macrophages (M2c) assume a regulatory phenotype in the presence of TGF$\beta$ and IL-10, two cytokines that are widely associated with Treg function. This is in addition to the induction of antiinflammatory phenotype in macrophages following treatment with glucocorticoids (118). Interestingly, the secretion of IL-10 is a characteristic feature of Mregs (119) and IL-10 plays a major role in the function of Mregs. For example, targeted disruption of IL-10 receptor signaling in macrophages leads to the spontaneous development of severe colitis (120). Since Tregs are also major producers of IL-10, it is conceivable that macrophage/Treg crosstalk via IL-10 plays a significant role in maintenance of tolerance. Indeed, Tregs are able to direct macrophage differentiation to the M2 regulatory phenotype in a mechanism that has been shown to be dependent on IL-10 and TGF- $\beta$ (117, 121-123). Tregs have also been shown to induce macrophage regulatory phenotype through other mechanisms. Miwa et al showed that Tregs play 
a role in the maintenance of fetal-maternal tolerance through the upregulation of the enzyme indoleamine 2,3-dioxygenase (IDO) in monocytes (124). Venet et al. showed that Tregs play a major role in regulation of monocyte survival by promoting monocyte apoptosis in a mechanism dependent on the Fas/Fas ligand pathway (125).

These studies indicate that Mreg/Treg cross-talk is central to the maintenance of immune tolerance. Indeed, M2 macrophages have also been shown to induce Tregs $(126,127)$ and similar to Tregs, Mregs have shown therapeutic efficacy in the experimental treatment of inflammatory diseases like allergy and type 1 diabetes $(128,129)$ highlighting the role of Mregs in immune tolerance. In addition to the induction of Tregs by IL-10 and TGF- $\beta$ activity, the ability of Mregs to induce Tregs has been shown to involve the production of reactive oxygen species (ROS). Disruption of the NAPDH-oxidase complex which is involved in ROS production impairs induction of Tregs by macrophages (130). Also, mice with reduced ROS production ability is more susceptible to autoimmune diseases compared to their wild type litter mates highlighting the role of macrophage ROS in immune tolerance (131). Hence, Mreg/Treg cross-talk is a major mechanism of immune tolerance that needs to be further explored.

\section{TREGS AND NEUTROPHILS}

Neutrophils are one of the first responder cells of the innate immune system during bacterial infection and inflammation and constitute a hallmark of innate immunity $(132,133)$. They are the most abundant type of leukocytes in humans and express all known TLRs except TLR3. Hence, neutrophils are critical for the activation of innate immune defenses and defective neutrophil function leads to increased susceptibility to infections (134). The role of neutrophils in shaping the innate and adaptive immune responses has been extensively reviewed $(135,136)$. Here, we will focus on Treg/neutrophil interaction and the regulatory role of neutrophils in immunity.

There is accumulating evidence that neutrophils can be polarized to attain unique phenotypes in response to the microenvironment. For example, Fridlender et al. described the characterization of anti-tumorigenic neutrophil (N1 phenotype) and pro-tumorigenic neutrophil (N2 phenotype) in mice (137). The presence of TGF- $\beta$ in the tumor microenvironment induces N2 neutrophils while blockade of TGF- $\beta$ favors the N1 phenotype. There is also evidence that neutrophils which are renowned for their pro-inflammatory activity can exhibit regulatory and immuno-suppressive functions through various mechanisms. For example, Schmielau et al. demonstrated that neutrophil-derived hydrogen peroxide suppresses $\mathrm{T}$ cell responses in patients with cancer (138). This finding was confirmed by the work of Pillay et al. which showed that neutrophil-derived hydrogen peroxide suppresses $\mathrm{T}$ cell responses in sepsis through the expression of Mac-1 (139). These immuno-suppressive neutrophils were characterized as $\mathrm{CD} 16^{+} \mathrm{CD} 54^{\text {high }}$ cells in contrast to the classical $\mathrm{CD} 16^{+} \mathrm{CD} 54^{\text {lo }}$ neutrophils (139). The suppressive function of neutrophils has also been demonstrated in viral infections. Bowers et al. demonstrated that neutrophils purified from the blood of HIV1-infected patients suppress T cell function through PD-L1/PD-1 interaction and production of ROS (140).

In addition to ROS production, studies have shown that the regulatory function of neutrophils can be associated with cytokine production. Again, the cytokine IL-10 has been implicated in this regard. Doz et al. demonstrated that IL10-producing neutrophils inhibit Th17 cell responses during mycobacterial infection (141). This was supported by the work of Zhang et al. which showed that co-activation of Syk kinase and MyD88 adaptor protein pathways leads to IL-10 production by murine neutrophils which dampen immune response in mycobacterial infection (142).

There is evidence of cross-talk between Tregs and neutrophils and there is significant interest in the role of Treg/neutrophil interaction in the maintenance of immune homeostasis. The work of Himmel et al. showed that Tregs are able to induce neutrophil recruitment through the production of CXCL8 (143). It is also conceivable that IL-10 production by Tregs can modulate neutrophil function and vice versa. Lewkowicz et al. showed that activated Tregs upregulate the expression of suppressor of cytokine signaling 3 (SOCS 3) in neutrophils and induce IL-10 and TGF- $\beta$ production (144).

Overall, it is important to note that the relationship between Tregs and neutrophils has been severely underexplored. An important area of interest is Treg/neutrophil interaction in inflammatory and autoimmune diseases. The pro-inflammatory function of neutrophils in the promotion and pathogenesis of several autoimmune diseases like vasculitis (145), rheumatoid arthritis (146), and systemic lupus erythematosus (147) has been well-described. Interestingly, defective Treg function has been demonstrated in all these diseases and Treg therapy has proven to be useful in their management (148). Therefore, one can speculate that defective Treg function is associated with exaggerated neutrophil activity. Indeed, we and others have found this to be the case. Richards et al. showed that Tregs limit inflammation in the skin by inhibiting neutrophil accumulation and survival (149). We recently showed that reduced Treg numbers in mice leads to exaggerated neutrophil activity resulting in mortality in endotoxic shock (150). We also found that Tregs regulate survival and activity of human and murine neutrophils and co-culture of Tregs and neutrophils increases neutrophil apoptosis (150). This is in line with the work of Lewkowicz et al. which showed that LPS-activated Tregs inhibit neutrophil function and promote their apoptosis (151). More work is required to delineate the role of Treg/neutrophil interaction in autoimmune and inflammatory diseases and this remains an active area of investigation in our laboratory.

\section{TREGS AND GAMMA DELTA $(\gamma \delta)$ T CELLS}

Majority of $\mathrm{T}$ cells develop in the thymus, have $\mathrm{T}$ cell receptor (TCR) composed of $\alpha \beta$ chains, and are mostly found in peripheral lymphoid organs. In contrast, there are a sub-population of $\mathrm{T}$ cells that develop within and outside the thymus, have TCR 
composed of $\gamma \delta$ chains and are very few in peripheral lymphoid organs but abundant in intra-epithelial compartments. This population of $\mathrm{T}$ cells are called $\gamma \delta \mathrm{T}$ cells (152). $\gamma \delta \mathrm{T}$ cells are considered innate immune cells due to their innate-like characteristics. Notably, unlike conventional T cells, they can be activated without the help of APCs and do not require MHC class I or II peptide presentation (153). Also, similar to innate immune cells, $\gamma \delta \mathrm{T}$ cells have been shown to carry out phagocytosis (154). The biology and role of $\gamma \delta \mathrm{T}$ cells in immunity has been comprehensively reviewed by others (155-157) and the reader is referred to these excellent reviews for detailed information on these aspects of $\gamma \delta$ T cells.

There is evidence that $\gamma \delta \mathrm{T}$ cells possess both inflammatory and regulatory properties. Proinflammatory $\gamma \delta \mathrm{T}$ cells are classified according to their production of either IFN- $\gamma$ or IL17 (158-160) and have been implicated in the pathogenesis of several autoimmune diseases (161) including $\operatorname{EAE}(162,163)$ and collagen-induced arthritis (164). In contrast, stimulation of $\gamma \delta \mathrm{T}$ cells in the presence of TGF- $\beta$ leads to the induction of FOXP3 expressing $\gamma \delta \mathrm{T}$ cells with suppressive phenotype $(165,166)$. These appropriately called regulatory $\gamma \delta \mathrm{T}$ cells have been shown to exert their suppressive function through the production of IL-10 and TGF- $\beta$ to inhibit T cell activation and proliferation (165-168).

Few studies have examined the bilateral relationship between Tregs and $\gamma \delta \mathrm{T}$ cells and there is evidence of cross-talk between these two populations. Since, $\gamma \delta \mathrm{T}$ cells with regulatory phenotype are induced in the presence of IL-10 and TGF$\beta$ and Tregs secrete these cytokines, it follows that Tregs can induce $\gamma \delta \mathrm{T}$ cells with regulatory phenotype. Indeed, this has been demonstrated recently. Park et al. showed that Tregs maintain intestinal homeostasis by suppressing $\gamma \delta \mathrm{T}$ cells (169). They showed that $\mathrm{CD} 4^{+} \mathrm{T}$ cell specific deletion of the phosphoinositide dependent protein kinase $1(P d k 1)$ gene leads to defective Treg function and the constitutive activation of colitis-inducing $\gamma \delta \mathrm{T}$ cells which is inhibited by adoptive transfer of wild-type Tregs (169). The findings of Park et al. was confirmed by Yurchenko et al. who unequivocally demonstrated the role of Tregs in regulating pathogenic $\gamma \delta \mathrm{T}$ cells in the intestines (170).

Other studies have also demonstrated the ability of Tregs to regulate the function of $\gamma \delta \mathrm{T}$ cells. Li et al. showed that Tregs inhibited cytokine production by $\gamma \delta \mathrm{T}$ cells in response to $M$ tuberculosis antigen (171). Xu et al. showed that in pediatric epilepsy associated with inflammation of the central nervous system, there is increase in the number of $\gamma \delta \mathrm{T}$ cells and this corresponds to a decrease in Tregs numbers in the epileptogenic lesions (172). Additionally, they demonstrated that seizures were significantly decreased following inhibition of $\gamma \delta \mathrm{T}$ cells activity or adoptive transfer of Tregs into these mice. Overall, these findings highlight the ability of Tregs to regulate the function of another innate immune cell $-\gamma \delta \mathrm{T}$ cells.

\section{CONCLUDING REMARKS}

There is unequivocal experimental evidence of the role of Tregs in the maintenance of immune tolerance (20). Initial studies focused on the role of Tregs in the regulation of $\mathrm{CD}^{+} \mathrm{Th}$ cells $(52,53,60)$. However, as the knowledge of Tregs biology increased, they were shown to be able to regulate other cells of the adaptive immune system including $\mathrm{CD} 8^{+} \mathrm{T}$ cells and $\mathrm{B}$ cells $(5,6)$. In this review, we highlighted the burgeoning function of Tregs in the regulation of cells of the innate immune system including dendritic cells, macrophages, neutrophils, and $\gamma \delta \mathrm{T}$ cells. In addition to these cell types, Tregs have also been shown to regulate the function of other innate immune cells including natural killer (NK) (173) and innate lymphoid (ILC) cells (174). Indeed, as shown in Figure 1, this cross-talk between Tregs and innate immune cells is important for maintenance of immune tolerance and regulating the pathogenesis of inflammatory diseases. Hence, Tregs appear to be the master-regulatory cell type necessary for immune tolerance involving both the innate and adaptive immunity (175).

Previous studies have highlighted the role of Tregs in regulating pathogenic $\mathrm{CD} 4^{+} \mathrm{T}$ cells $(52,53,60)$. In this review, we emphasize the significance of Tregs in regulating innate immune cells and that defective Treg function is associated with aggravated inflammatory response by innate immune cells. We postulate that defective Treg function simultaneously affects adaptive immune cells and innate immune cells in different disease models. For example, we previously showed that depletion of Tregs leads to exaggerated $\mathrm{CD} 4^{+} \mathrm{T}$ cell response in bacteria and LPS-induced acute inflammation models (61). In another study, we demonstrated that reduced Treg numbers also leads to enhanced neutrophil activity in LPS-induced inflammation (150). Hence, it follows that reduced Treg numbers simultaneously affects $\mathrm{CD} 4^{+} \mathrm{T}$ cells and neutrophils. It is worthy of note that defective Treg function can lead to exaggerated activity of adaptive immune cells like $\mathrm{CD} 4{ }^{+} \mathrm{T}$ cells, which in turn will lead to the aggravated immune response of innate immune cells like macrophages (61). Likewise, defective Treg function can also lead to exaggerated activity of innate immune cells whose cytokine secretion will aggravate the immune response of adaptive immune cells. This highlights the master regulatory role of Tregs in the maintenance of immune homeostasis.

A possible explanation of the simultaneous effect of Treg function on innate and adaptive immune cells is the ability of Treg cells to extract ligands from APCs by trogocytosis (176). For example, previous studies have shown that Tregs exert their suppression through the inhibitory receptor CTLA-4 $(177,178)$. It is worthy of note that CTLA-4 shares its ligands (CD80 and CD86) with the co-stimulatory receptor CD28. Interestingly, Qureshi et al. showed that Tregs suppress $\mathrm{T}$ cell response by using CTLA-4 to extract CD80 or CD86 from APCs leading to impaired co-stimulation of $\mathrm{T}$ cells through CD28 (179). This implies that decrease in number of Tregs relative to APCs will limit trogocytosis of CD80 and CD86 by CTLA- $4^{+}$Tregs leading to higher $\mathrm{CD} 28$ costimulation and more aggressive $\mathrm{T}$ cell response (180). Another study showed that Tregs that acquired CD86 from DCs have enhanced ability to suppress $\mathrm{T}$ cell responses (176). Overall, these studies indicate that co-operation between Tregs and APCs shapes immune homeostasis.

The regulation of innate immunity by Tregs is not surprising. The immune system is made up of a complex network of 
cells that are intricately involved in the immune network. Hence, as shown in Figure 1, it is understandable that IL-10producing innate immune cells induce Tregs and vice versa. Indeed, cellular cytokine activity is a proven way of recruiting responder cells for immune function. Delineating the complex interaction among different cell types is a daunting task and remains the subject of investigation in several laboratories around the world. Although the distinction between innate and adaptive immunity is one of the basic tenets of immunology, there is general agreement that the co-operation between these two arms of the immune system is a major determinant of resistance or susceptibility of the host to pathogen invasion. Recently, accumulating evidence suggests that there is a fine line separating the two arms of the immune system. As highlighted in this review, Treg/DC, Treg/macrophage Treg/neutrophil, and Treg/ $\gamma \delta \mathrm{T}$ cell cross-talks are critical for the maintenance of

\section{REFERENCES}

1. Sprent J, Kishimoto H. The thymus and central tolerance. Philos Trans R Soc Lond B Biol Sci. (2001) 356:609-16. doi: 10.1098/rstb.2001.0846

2. Sakaguchi S, Wing K, Miyara M. Regulatory T cells - a brief history and perspective. Eur J Immunol. (2007) 37(Suppl. 1):S116-23. doi: 10.1002/eji.200737593

3. Sakaguchi S, Miyara M, Costantino CM, Hafler DA. FOXP3+ regulatory T cells in the human immune system. Nat Rev Immunol. (2010) 10:490-500. doi: $10.1038 /$ nri2785

4. Weber SE, Harbertson J, Godebu E, Mros GA, Padrick RC, Carson BD, et al. Adaptive islet-specific regulatory $\mathrm{CD} 4 \mathrm{~T}$ cells control autoimmune diabetes and mediate the disappearance of pathogenic Th1 cells in vivo. J Immunol. (2006) 176:4730-9. doi: 10.4049/jimmunol.176.8.4730

5. Strauss L, Bergmann C, Whiteside TL. Human circulating CD4+CD25highFoxp3+ regulatory $\mathrm{T}$ cells kill autologous $\mathrm{CD} 8+$ but not CD4+ responder cells by Fas-mediated apoptosis. J Immunol. (2009) 182:1469-80. doi: 10.4049/jimmunol.182.3.1469

6. Lim HW, Hillsamer $\mathrm{P}$, Banham AH, Kim $\mathrm{CH}$. Cutting edge: direct suppression of $\mathrm{B}$ cells by $\mathrm{CD} 4+\mathrm{CD} 25+$ regulatory $\mathrm{T}$ cells. J Immunol. (2005) 175:4180-3. doi: 10.4049/jimmunol.175.7.4180

7. Xu A, Liu Y, Chen W, Wang J, Xue Y, Huang F, et al. TGF$\beta$-induced regulatory $T$ cells directly suppress $B$ cell responses through a noncytotoxic mechanism. I Immunol. (2016) 196:3631-41. doi: 10.4049/jimmunol.1501740

8. Gershon RK, Kondo K. Cell interactions in the induction of tolerance: the role of thymic lymphocytes. Immunology. (1970) 18:723-37.

9. Gershon RK, Cohen P, Hencin R, Liebhaber SA. Suppressor T cells. J Immunol. (1972) 108:586-90.

10. Okumura K, Tada T. Suppression of hapten-specific antibody response by carrier-specific T cells. Nat New Biol. (1973) 245:180-2.

11. Rich RR, Pierce CW. Biological expressions of lymphocyte activation. II. Generation of a population of thymus-derived suppressor lymphocytes. J Exp Med. (1973) 137:649-59.

12. Kerbel RS, Eidinger D. Enhanced immune responsiveness to a thymusindependent antigen early after adult thymectomy: evidence for shortlived inhibitory thymus-derived cells. Eur J Immunol. (1972) 2:114-8. doi: 10.1002/eji.1830020204

13. Vadas MA, Miller JF, McKenzie IF, Chism SE, Shen FW, Boyse $\mathrm{EA}$, et al. Ly and Ia antigen phenotypes of $\mathrm{T}$ cells involved in delayed-type hypersensitivity and in suppression. J Exp Med. (1976) 144:10-9.

14. Cantor H, Shen FW, Boyse EA. Separation of helper T cells from suppressor $\mathrm{T}$ cells expressing different Ly components. II. Activation by antigen: after immunization, antigen-specific suppressor and helper activities are mediated by distinct T-cell subclasses. J Exp Med. (1976) 143:1391-40. immune tolerance and prevention of autoimmune diseases. Thus, the immune system is a highly integrated network and although stratifying immune function can be beneficial, immunity is better understood in the context of cooperative functionality of cells.

\section{AUTHOR CONTRIBUTIONS}

EO did all literature search required for the review and wrote the first draft of the manuscript. JU edited and corrected the manuscript draft for publication.

\section{FUNDING}

This study was provided by the Canadian Institutes of Health Research and the Manitoba Health Research Council.
15. Murphy DB, Herzenberg LA, Okumura K, Herzenberg LA, McDevitt HO. A new I subregion (I-J) marked by a locus (Ia-4) controlling surface determinants on suppressor T lymphocytes. J Exp Med. (1976) 144:699-712.

16. Okumura K, Herzenberg LA, Murphy DB, McDevitt HO, Herzenberg LA. Selective expression of H-2 (i-region) loci controlling determinants on helper and suppressor T lymphocytes. J Exp Med. (1976) 144:685-98.

17. Kronenberg M, Steinmetz M, Kobori J, Kraig E, Kapp JA, Pierce CW, et al. RNA transcripts for I-J polypeptides are apparently not encoded between the I-A and I-E subregions of the murine major histocompatibility complex. Proc Natl Acad Sci USA. (1983) 80:5704-8.

18. Kobori JA, Strauss E, Minard K, Hood L. Molecular analysis of the hotspot of recombination in the murine major histocompatibility complex. Science. (1986) 234:173-9.

19. Sakaguchi S, Sakaguchi N, Asano M, Itoh M, Toda M. Immunologic selftolerance maintained by activated $\mathrm{T}$ cells expressing IL-2 receptor alphachains (CD25). Breakdown of a single mechanism of self-tolerance causes various autoimmune diseases. J Immunol. (1995) 155:1151-64.

20. Sakaguchi S. Regulatory T cells: key controllers of immunologic selftolerance. Cell. (2000) 101:455-8. doi: 10.1016/S0092-8674(00)80856-9

21. Groux H, O’Garra A, Bigler M, Rouleau M, Antonenko S, de Vries JE, et al. A CD4+ T-cell subset inhibits antigen-specific T-cell responses and prevents colitis. Nature. (1997) 389:737-42. doi: 10.1038/39614

22. Thornton AM, Shevach EM. CD4+CD25+ immunoregulatory T cells suppress polyclonal $\mathrm{T}$ cell activation in vitro by inhibiting interleukin 2 production. J Exp Med. (1998) 188:287-96.

23. Suri-Payer E, Amar AZ, Thornton AM, Shevach EM. CD4+CD25+ T cells inhibit both the induction and effector function of autoreactive $\mathrm{T}$ cells and represent a unique lineage of immunoregulatory cells. J Immunol. (1998) 160:1212-8.

24. Bennett CL, Christie J, Ramsdell F, Brunkow ME, Ferguson PJ, Whitesell $\mathrm{L}$, et al. The immune dysregulation, polyendocrinopathy, enteropathy, Xlinked syndrome (IPEX) is caused by mutations of FOXP3. Nat Genet. (2001) 27:20-1. doi: 10.1038/83713

25. Brunkow ME, Jeffery EW, Hjerrild KA, Paeper B, Clark LB, Yasayko SA, et al. Disruption of a new forkhead/winged-helix protein, scurfin, results in the fatal lymphoproliferative disorder of the scurfy mouse. Nat Genet. (2001) 27:68-73. doi: 10.1038/83784

26. Fontenot JD, Gavin MA, Rudensky AY. Foxp3 programs the development and function of CD4+CD25+ regulatory T cells. Nat Immunol. (2003) 4:330-6. doi: 10.1038/ni904ni904

27. Hori S, Nomura T, Sakaguchi S. Control of regulatory T cell development by the transcription factor Foxp3. Science. (2003) 299:1057-61. doi: $10.1126 /$ science. 1079490

28. Khattri R, Cox T, Yasayko S-A, Ramsdell F. An essential role for Scurfin in CD4+CD25+ T regulatory cells. Nat Immunol. (2003) 4:337-42. doi: $10.1038 /$ ni909 
29. Wing K, Sakaguchi S. Regulatory T cells exert checks and balances on self tolerance and autoimmunity. Nat Immunol. (2010) 11:7-13. doi: $10.1038 /$ ni. 1818

30. Josefowicz SZ, Lu L-F, Rudensky AY. Regulatory T cells: mechanisms of differentiation and function. Annu Rev Immunol. (2012) 30:531-64. doi: 10.1146/annurev.immunol.25.022106.141623

31. Grazia Roncarolo M, Gregori S, Battaglia M, Bacchetta R, Fleischhauer $\mathrm{K}$, Levings $\mathrm{MK}$. Interleukin-10-secreting type 1 regulatory $\mathrm{T}$ cells in rodents and humans. Immunol Rev. (2006) 212:28-50. doi: 10.1111/j.0105-2896.2006.00420.x

32. Vieira PL, Christensen JR, Minaee S, O’Neill EJ, Barrat FJ, Boonstra A, et al. IL-10-secreting regulatory T cells do not express Foxp3 but have comparable regulatory function to naturally occurring $\mathrm{CD} 4+\mathrm{CD} 25+$ regulatory T cells. J Immunol. (2004) 172:5986-93. doi: 10.4049/jimmunol.172.10.5986

33. O'Garra A, Vieira PL, Vieira P, Goldfeld AE. IL-10-producing and naturally occurring CD4+ Tregs: limiting collateral damage. J Clin Invest. (2004) 114:1372-8. doi: 10.1172/JCI23215

34. Gregori S, Tomasoni D, Pacciani V, Scirpoli M, Battaglia M, Magnani $\mathrm{CF}$, et al. Differentiation of type $1 \mathrm{~T}$ regulatory cells ( $\mathrm{Tr} 1)$ by tolerogenic DC-10 requires the IL-10-dependent ILT4/HLA-G pathway. Blood. (2010) 116:935-44. doi: 10.1182/blood-2009-07-234872

35. Brockmann L, Gagliani N, Steglich B, Giannou AD, Kempski J, Pelczar P, et al. IL-10 receptor signaling is essential for TR1 cell function in vivo. $J$ Immunol. (2017) 198:1130-41. doi: 10.4049/jimmunol.1601045

36. Mascanfroni ID, Takenaka MC, Yeste A, Patel B, Wu Y, Kenison JE, et al. Metabolic control of type 1 regulatory $\mathrm{T}$ cell differentiation by AHR and HIF1- $\alpha$. Nat Med. (2015) 21:638-46. doi: 10.1038/nm.3868

37. Mandapathil M, Szczepanski MJ, Szajnik M, Ren J, Jackson EK, Johnson JT, et al. Adenosine and prostaglandin E2 cooperate in the suppression of immune responses mediated by adaptive regulatory T cells. J Biol Chem. (2010) 285:27571-80. doi: 10.1074/jbc.M110.127100

38. Yao Y, Vent-Schmidt J, McGeough MD, Wong M, Hoffman HM, Steiner TS, et al. Tr1 cells, but not Foxp3+ regulatory T cells, suppress NLRP3 inflammasome activation via an IL-10-dependent mechanism. J Immunol. (2015) 195:488-97. doi: 10.4049/jimmunol.1403225

39. Gagliani N, Jofra T, Valle A, Stabilini A, Morsiani C, Gregori S, et al. Transplant tolerance to pancreatic islets is initiated in the graft and sustained in the spleen. Am J Transplant. (2013) 13:1963-75. doi: 10.1111/ajt.12333

40. Roncarolo MG, Gregori S, Bacchetta R, Battaglia M, Gagliani N. The biology of $\mathrm{T}$ regulatory type 1 Cells and their therapeutic application in immune-mediated diseases. Immunity. (2018) 49:1004-19. doi: 10.1016/j.immuni.2018.12.001

41. Roncarolo MG, Gregori S, Bacchetta R, Battaglia M. Tr1 cells and the counter-regulation of immunity: natural mechanisms and therapeutic applications. Curr Top Microbiol Immunol. (2014) 380:39-68. doi: 10.1007/978-3-662-43492-5_3

42. Palomares O, Rückert B, Jartti T, Kücüksezer UC, Puhakka T, Gomez E, et al. Induction and maintenance of allergen-specific FOXP3+ Treg cells in human tonsils as potential first-line organs of oral tolerance. J Allergy Clin Immunol. (2012) 129:510-20.e1-9. doi: 10.1016/j.jaci.2011.09.031

43. Zenclussen AC, Gerlof K, Zenclussen ML, Ritschel S, Zambon Bertoja $\mathrm{A}$, Fest $\mathrm{S}$, et al. Regulatory $\mathrm{T}$ cells induce a privileged tolerant microenvironment at the fetal-maternal interface. Eur J Immunol. (2006) 36:82-94. doi: 10.1002/eji.200535428

44. Jonuleit H, Schmitt E, Kakirman H, Stassen M, Knop J, Enk AH. Infectious tolerance: human $\mathrm{CD} 25(+)$ regulatory $\mathrm{T}$ cells convey suppressor activity to conventional CD4(+) T helper cells. J Exp Med. (2002) 196:255-60. doi: 10.1084/jem.20020394

45. Di Ianni M, Falzetti F, Carotti A, Terenzi A, Castellino F, Bonifacio E, et al. Tregs prevent GVHD and promote immune reconstitution in HLA-haploidentical transplantation. Blood. (2011) 117:3921-8. doi: 10.1182/blood-2010-10-311894

46. Akbari O, Freeman GJ, Meyer EH, Greenfield EA, Chang TT, Sharpe AH, et al. Antigen-specific regulatory T cells develop via the ICOS-ICOS-ligand pathway and inhibit allergen-induced airway hyperreactivity. Nat Med. (2002) 8:1024-32. doi: 10.1038/nm745

47. Brincks EL, Roberts AD, Cookenham T, Sell S, Kohlmeier JE, Blackman $\mathrm{MA}$, et al. Antigen-specific memory regulatory CD4+Foxp3+ T cells control memory responses to influenza virus infection. J Immunol. (2013) 190:343846. doi: 10.4049/jimmunol.1203140

48. Morgan ME, Sutmuller RP, Witteveen HJ, van Duivenvoorde LM, Zanelli E, Melief CJ, et al. CD25+ cell depletion hastens the onset of severe disease in collagen-induced arthritis. Arthritis Rheum. (2003) 48:1452-60. doi: 10.1002/art.11063

49. de Kleer IM, Wedderburn LR, Taams LS, Patel A, Varsani H, Klein M, et al. $\mathrm{CD} 4+\mathrm{CD} 25$ bright regulatory $\mathrm{T}$ cells actively regulate inflammation in the joints of patients with the remitting form of juvenile idiopathic arthritis. $J$ Immunol. (2004) 172:6435-43. doi: 10.4049/jimmunol.172.10.6435

50. Lawson CA, Brown AK, Bejarano V, Douglas SH, Burgoyne $\mathrm{CH}$, Greenstein AS, et al. Early rheumatoid arthritis is associated with a deficit in the $\mathrm{CD} 4+\mathrm{CD} 25$ high regulatory $\mathrm{T}$ cell population in peripheral blood. Rheumatology. (2006) 45:1210-7. doi: 10.1093/rheumatology/kel089

51. Desreumaux P, Foussat A, Allez M, Beaugerie L, Hébuterne X, Bouhnik Y, et al. Safety and efficacy of antigen-specific regulatory T-cell therapy for patients with refractory Crohn's disease. Gastroenterology. (2012) 143:120717.e2. doi: 10.1053/j.gastro.2012.07.116

52. Mahne AE, Klementowicz JE, Chou A, Nguyen V, Tang Q. Therapeutic regulatory $\mathrm{T}$ cells subvert effector $\mathrm{T}$ cell function in inflamed islets to halt autoimmune diabetes. J Immunol. (2015) 194:3147-55. doi: 10.4049/jimmunol.1402739

53. Schneider A, Long SA, Cerosaletti K, Ni CT, Samuels P, Kita M, et al. In active relapsing-remitting multiple sclerosis, effector $\mathrm{T}$ cell resistance to adaptive Tregs involves IL-6-mediated signaling. Sci Transl Med. (2013) 5:170ra15. doi: 10.1126/scitranslmed.3004970

54. Verhagen J, Akdis M, Traidl-Hoffmann C, Schmid-Grendelmeier P, Hijnen $\mathrm{D}$, Knol EF, et al. Absence of T-regulatory cell expression and function in atopic dermatitis skin. J Allergy Clin Immunol. (2006) 117:176-83. doi: 10.1016/j.jaci.2005.10.040

55. Venet F, Chung C-S, Kherouf H, Geeraert A, Malcus C, Poitevin $\mathrm{F}$, et al. Increased circulating regulatory $\mathrm{T}$ cells $(\mathrm{CD} 4(+) \mathrm{CD} 25$ $(+) \mathrm{CD} 127(-))$ contribute to lymphocyte anergy in septic shock patients. Intensive Care Med. (2009) 35:678-86. doi: 10.1007/s00134-0081337-8

56. Heuer JG, Zhang T, Zhao J, Ding C, Cramer M, Justen KL, et al. Adoptive transfer of in vitro-stimulated $\mathrm{CD} 4+\mathrm{CD} 25+$ regulatory $\mathrm{T}$ cells increases bacterial clearance and improves survival in polymicrobial sepsis. J Immunol. (2005) 174:7141-6. doi: 10.4049/jimmunol.174.11.7141

57. Cambos $M$, Bélanger $B$, Jacques A, Roulet A, Scorza T. Natural regulatory $(\mathrm{CD} 4+\mathrm{CD} 25+\mathrm{FOXP}+) \mathrm{T}$ cells control the production of proinflammatory cytokines during Plasmodium chabaudi adami infection and do not contribute to immune evasion. Int J Parasitol. (2008) 38:229-38. doi: 10.1016/j.ijpara.2007.07.006

58. Lund JM, Hsing L, Pham TT, Rudensky AY. Coordination of early protective immunity to viral infection by regulatory T cells. Science. (2008) 320:1220-4. doi: 10.1126/science.1155209

59. Okeke EB, Okwor I, Mou Z, Jia P, Uzonna JE. CD4+CD25+ regulatory T cells attenuate lipopolysaccharide-induced systemic inflammatory responses and promotes survival in murine Escherichia coli infection. Shock. (2013) 40:65-73. doi: 10.1097/SHK.0b013e318296e65b

60. Eastaff-Leung N, Mabarrack N, Barbour A, Cummins A, Barry S. Foxp3+ regulatory $\mathrm{T}$ cells, Th17 effector cells, and cytokine environment in inflammatory bowel disease. J Clin Immunol. (2010) 30:80-9. doi: 10.1007/s10875-009-9345-1

61. Okeke EB, Okwor I, Uzonna JE. Regulatory T cells restrain CD4+ T cells from causing unregulated immune activation and hypersensitivity to lipopolysaccharide challenge. J Immunol. (2014) 193:655-62. doi: 10.4049/jimmunol.1303064

62. Steinman RM, Cohn ZA. Pillars Article: identification of a novel cell type in peripheral lymphoid organs of mice. I. Morphology, quantitation, tissue distribution. J. Exp. Med.1973. 137:1142-1162. J Immunol. (2007) 178:5-25.

63. Banchereau J, Steinman RM. Dendritic cells and the control of immunity. Nature. (1998) 392:245-52. doi: 10.1038/32588

64. Nace G, Evankovich J, Eid R, Tsung A. Dendritic cells and damageassociated molecular patterns: endogenous danger signals linking innate and adaptive immunity. J Innate Immun. (2012) 4:6-15. doi: 10.1159/0003 34245 
65. Steinman RM. Decisions about dendritic cells: past, present, and future. Annu Rev Immunol. (2012) 30:1-22. doi: 10.1146/annurev-immunol-100311-102839

66. Finkelman FD, Lees A, Birnbaum R, Gause WC, Morris SC. Dendritic cells can present antigen in vivo in a tolerogenic or immunogenic fashion. $J$ Immunol. (1996) 157:1406-14.

67. Hawiger D, Inaba K, Dorsett Y, Guo M, Mahnke K, Rivera M, et al. Dendritic cells induce peripheral $\mathrm{T}$ cell unresponsiveness under steady state conditions in vivo. J Exp Med. (2001) 194:769-79. doi: 10.1084/jem.194.6.769

68. Lutz MB, Schuler G. Immature, semi-mature and fully mature dendritic cells: which signals induce tolerance or immunity? Trends Immunol. (2002) 23:445-9. doi: 10.1016/S1471-4906(02)02281-0

69. Yamazaki S, Iyoda $\mathrm{T}$, Tarbell $\mathrm{K}$, Olson $\mathrm{K}$, Velinzon $\mathrm{K}$, Inaba $\mathrm{K}$, et al. Direct expansion of functional $\mathrm{CD} 25+\mathrm{CD} 4+$ regulatory $\mathrm{T}$ cells by antigen-processing dendritic cells. J Exp Med. (2003) 198:235-47. doi: 10.1084/jem.20030422

70. Yamazaki S, Bonito AJ, Spisek R, Dhodapkar M, Inaba K, Steinman RM. Dendritic cells are specialized accessory cells along with TGF- for the differentiation of Foxp3 + CD4+ regulatory T cells from peripheral Foxp3 precursors. Blood. (2007) 110:4293-302. doi: 10.1182/blood-2007-05-088831

71. Martín-Gayo E, Sierra-Filardi E, Corbí AL, Toribio ML. Plasmacytoid dendritic cells resident in human thymus drive natural Treg cell development. Blood. (2010) 115:5366-75. doi: 10.1182/blood-2009-10-248260

72. Kretschmer K, Apostolou I, Hawiger D, Khazaie K, Nussenzweig MC, von Boehmer $\mathrm{H}$. Inducing and expanding regulatory $\mathrm{T}$ cell populations by foreign antigen. Nat Immunol. (2005) 6:1219-27. doi: 10.1038/ni1265

73. Bettelli E, Carrier Y, Gao W, Korn T, Strom TB, Oukka M, et al. Reciprocal developmental pathways for the generation of pathogenic effector TH17 and regulatory T cells. Nature. (2006) 441:235-8. doi: 10.1038/nature04753

74. Wei J, Duramad O, Perng OA, Reiner SL, Liu Y-J, Qin FX-F. Antagonistic nature of $\mathrm{T}$ helper $1 / 2$ developmental programs in opposing peripheral induction of Foxp3+ regulatory T cells. Proc Natl Acad Sci USA. (2007) 104:18169-74. doi: 10.1073/pnas.0703642104

75. Wang L, Pino-Lagos K, de Vries VC, Guleria I, Sayegh MH, Noelle RJ. Programmed death 1 ligand signaling regulates the generation of adaptive Foxp3+CD4+ regulatory T cells. Proc Natl Acad Sci USA. (2008) 105:93316. doi: 10.1073/pnas. 0710441105

76. Couper KN, Blount DG, Riley EM. IL-10: the master regulator of immunity to infection. J Immunol. (2008) 180:5771-7. doi: 10.4049/jimmunol.180.9.5771

77. Loebbermann J, Schnoeller C, Thornton H, Durant L, Sweeney NP, Schuijs M, et al. IL-10 regulates viral lung immunopathology during acute respiratory syncytial virus infection in mice. PLoS ONE. (2012) 7:e32371. doi: 10.1371/journal.pone.0032371

78. Kühn R, Löhler J, Rennick D, Rajewsky K, Müller W. Interleukin-10-deficient mice develop chronic enterocolitis. Cell. (1993) 75:263-74.

79. Gazzinelli RT, Wysocka M, Hieny S, Scharton-Kersten T, Cheever A, Kühn $\mathrm{R}$, et al. In the absence of endogenous IL-10, mice acutely infected with Toxoplasma gondii succumb to a lethal immune response dependent on $\mathrm{CD} 4+\mathrm{T}$ cells and accompanied by overproduction of IL-12, IFN-gamma and TNF-alpha. J Immunol. (1996) 157:798-805.

80. Lim J-Y, Im K-I, Lee E-S, Kim N, Nam Y-S, Jeon Y-W, et al. Enhanced immunoregulation of mesenchymal stem cells by IL-10-producing type 1 regulatory T cells in collagen-induced arthritis. Sci Rep. (2016) 6:26851. doi: 10.1038/srep26851

81. Montes de Oca M, Kumar R, de Labastida Rivera F, Amante FH, Sheel M, Faleiro RJ, et al. Blimp-1-dependent IL-10 production by $\operatorname{Tr} 1$ cells regulates TNF-mediated tissue pathology. PLoS Pathog. (2016) 12:e1005398. doi: 10.1371/journal.ppat.1005398

82. Caux C, Massacrier C, Vanbervliet B, Barthelemy C, Liu YJ, Banchereau J. Interleukin 10 inhibits $\mathrm{T}$ cell alloreaction induced by human dendritic cells. Int Immunol. (1994) 6:1177-85.

83. Groux H, Bigler M, de Vries JE, Roncarolo MG. Interleukin-10 induces a long-term antigen-specific anergic state in human CD4+ T cells. J Exp Med. (1996) 184:19-29.

84. Nayyar A, Dawicki W, Huang H, Lu M, Zhang X, Gordon JR. Induction of prolonged asthma tolerance by IL-10-differentiated dendritic cells: differential impact on airway hyperresponsiveness and the Th2 immunoinflammatory response. J Immunol. (2012) 189:72-9. doi: 10.4049/jimmunol.1103286

85. Sato K, Yamashita N, Baba M, Matsuyama T. Modified myeloid dendritic cells act as regulatory dendritic cells to induce anergic and regulatory $\mathrm{T}$ cells. Blood. (2003) 101:3581-9. doi: 10.1182/blood-2002-09-2712

86. Iliev ID, Mileti E, Matteoli G, Chieppa M, Rescigno M. Intestinal epithelial cells promote colitis-protective regulatory T-cell differentiation through dendritic cell conditioning. Mucosal Immunol. (2009) 2:340-50. doi: $10.1038 / \mathrm{mi} .2009 .13$

87. Loevenich K, Ueffing K, Abel S, Hose M, Matuschewski K, Westendorf $\mathrm{AM}$, et al. DC-Derived IL-10 modulates pro-inflammatory cytokine production and promotes induction of CD4+IL-10+ regulatory $\mathrm{T}$ cells during Plasmodium yoelii infection. Front Immunol. (2017) 8:152. doi: 10.3389/fimmu.2017.00152

88. Raker VK, Domogalla MP, Steinbrink K. Tolerogenic dendritic cells for regulatory $\mathrm{T}$ cell induction in man. Front Immunol. (2015) 6:569. doi: $10.3389 /$ fimmu.2015.00569

89. Chen W, Konkel JE. Development of thymic Foxp3(+) regulatory T cells: TGF- $\beta$ matters. Eur J Immunol. (2015) 45:958-65. doi: 10.1002/eji.201444999

90. Liu Y, Zhang P, Li J, Kulkarni AB, Perruche S, Chen W. A critical function for TGF-beta signaling in the development of natural CD4+CD25+Foxp3+ regulatory T cells. Nat Immunol. (2008) 9:632-40. doi: 10.1038/ni.1607

91. Konkel JE, Zhang D, Zanvit P, Chia C, Zangarle-Murray T, Jin W, et al. Transforming growth factor- $\beta$ signaling in regulatory $\mathrm{T}$ cells controls $\mathrm{T}$ helper-17 cells and tissue-specific immune responses. Immunity. (2017) 46:660-74. doi: 10.1016/j.immuni.2017.03.015

92. Shull MM, Ormsby I, Kier AB, Pawlowski S, Diebold RJ, Yin M, et al. Targeted disruption of the mouse transforming growth factor-beta 1 gene results in multifocal inflammatory disease. Nature. (1992) 359:693-9. doi: 10.1038/359693a0

93. Andersson J, Tran DQ, Pesu M, Davidson TS, Ramsey H, O'Shea JJ, et al. CD4+ FoxP3 + regulatory $\mathrm{T}$ cells confer infectious tolerance in a TGF-beta-dependent manner. J Exp Med. (2008) 205:1975-81. doi: $10.1084 /$ jem. 20080308

94. Laouar Y, Town T, Jeng D, Tran E, Wan Y, Kuchroo VK, et al. TGFbeta signaling in dendritic cells is a prerequisite for the control of autoimmune encephalomyelitis. Proc Natl Acad Sci USA. (2008) 105:1086570. doi: 10.1073/pnas. 0805058105

95. Yamazaki S, Dudziak D, Heidkamp GF, Fiorese C, Bonito AJ, Inaba $\mathrm{K}$, et al. $\mathrm{CD} 8+\mathrm{CD} 205+$ splenic dendritic cells are specialized to induce Foxp3+ regulatory T cells. J Immunol. (2008) 181:6923-33. doi: 10.4049/jimmunol.181.10.6923

96. Travis MA, Reizis B, Melton AC, Masteller E, Tang Q, Proctor JM, et al. Loss of integrin alpha(v)beta8 on dendritic cells causes autoimmunity and colitis in mice. Nature. (2007) 449:361-5. doi: 10.1038/nature06110

97. Worthington JJ, Kelly A, Smedley C, Bauché D, Campbell S, Marie JC, et al. Integrin $\alpha v \beta 8$-mediated TGF- $\beta$ activation by effector regulatory $\mathrm{T}$ cells is essential for suppression of T-cell-mediated inflammation. Immunity. (2015) 42:903-15. doi: 10.1016/j.immuni.2015.04.012

98. Liénart S, Merceron R, Vanderaa C, Lambert F, Colau D, Stockis J, et al. Structural basis of latent TGF- $\beta 1$ presentation and activation by GARP on human regulatory $\mathrm{T}$ cells. Science. (2018) 362:952-6. doi: $10.1126 /$ science.aau2909

99. Cuende J, Liénart S, Dedobbeleer O, van der Woning B, De Boeck G, Stockis J, et al. Monoclonal antibodies against GARP/TGF- $\beta 1$ complexes inhibit the immunosuppressive activity of human regulatory T cells in vivo. Sci Transl Med. (2015) 7:284ra56. doi: 10.1126/scitranslmed.aaa1983

100. Stockis J, Liénart S, Colau D, Collignon A, Nishimura SL, Sheppard D, et al. Blocking immunosuppression by human Tregs in vivo with antibodies targeting integrin $\alpha \mathrm{V} \beta 8$. Proc Natl Acad Sci USA. (2017) 114:E10161-8. doi: 10.1073 /pnas.1710680114

101. Iwata M, Yokota A. Retinoic acid production by intestinal dendritic cells. Vitam Horm. (2011) 86:127-52. doi: 10.1016/B978-0-12-386960-9.00006-X

102. Kang SG, Lim HW, Andrisani OM, Broxmeyer HE, Kim CH. Vitamin A metabolites induce gut-homing FoxP3+ regulatory $\mathrm{T}$ cells. J Immunol. (2007) 179:3724-33. doi: 10.4049/jimmunol.179. 6.3724 
103. Wang J, Huizinga TWJ, Toes REM. De novo generation and enhanced suppression of human $\mathrm{CD} 4+\mathrm{CD} 25+$ regulatory $\mathrm{T}$ cells by retinoic acid. $J$ Immunol. (2009) 183:4119-26. doi: 10.4049/jimmunol.0901065

104. Mucida D, Pino-Lagos K, Kim G, Nowak E, Benson MJ, Kronenberg M, et al. Retinoic acid can directly promote TGF-beta-mediated Foxp3(+) Treg cell conversion of naive T cells. Immunity. (2009) 30:471-2; author reply 472-3. doi: 10.1016/j.immuni.2009.03.008

105. Coombes JL, Siddiqui KRR, Arancibia-Cárcamo CV, Hall J, Sun C$\mathrm{M}$, Belkaid Y, et al . A functionally specialized population of mucosal CD103+ DCs induces Foxp3+ regulatory $\mathrm{T}$ cells via a TGF-beta and retinoic acid-dependent mechanism. J Exp Med. (2007) 204:1757-64. doi: 10.1084/jem.20070590

106. Iwata M, Hirakiyama A, Eshima Y, Kagechika H, Kato C, Song S-Y. Retinoic acid imprints gut-homing specificity on T cells. Immunity. (2004) 21:527-38. doi: 10.1016/j.immuni.2004.08.011

107. Ohoka Y, Yokota-Nakatsuma A, Maeda N, Takeuchi H, Iwata M. Retinoic acid and GM-CSF coordinately induce retinal dehydrogenase 2 (RALDH2) expression through cooperation between the RAR/RXR complex and Sp1 in dendritic cells. PLoS ONE. (2014) 9:e96512. doi: 10.1371/journal.pone.0096512

108. von Boehmer H. Oral tolerance: is it all retinoic acid? J Exp Med. (2007) 204:1737-9. doi: 10.1084/jem.20071251

109. Siewert C, Menning A, Dudda J, Siegmund K, Lauer U, Floess S, et al. Induction of organ-selective $\mathrm{CD} 4+$ regulatory $\mathrm{T}$ cell homing. Eur J Immunol. (2007) 37:978-89. doi: 10.1002/eji.200636575

110. Balmer JE, Blomhoff R. Gene expression regulation by retinoic acid. J Lipid Res. (2002) 43:1773-808. doi: 10.1194/jlr.R100015-JLR200

111. Guilliams M, Crozat K, Henri S, Tamoutounour S, Grenot P, Devilard E, et al. Skin-draining lymph nodes contain dermis-derived CD103(-) dendritic cells that constitutively produce retinoic acid and induce Foxp $3(+)$ regulatory $\mathrm{T}$ cells. Blood. (2010) 115:1958-68. doi: 10.1182/blood-2009-09-245274

112. Kono H, Rock KL. How dying cells alert the immune system to danger. Nat Rev Immunol. (2008) 8:279-89. doi: 10.1038/nri2215

113. Cavaillon JM. Cytokines and macrophages. Biomed Pharmacother. (1994) 48:445-53.

114. Gordon S. Alternative activation of macrophages. Nat Rev Immunol. (2003) 3:23-35. doi: 10.1038/nri978

115. Martinez FO, Sica A, Mantovani A, Locati M. Macrophage activation and polarization. Front Biosci. (2008) 13:453-61. doi: 10.2741/2692

116. Fleming BD, Mosser DM. Regulatory macrophages: setting the threshold for therapy. Eur J Immunol. (2011) 41:2498-502. doi: 10.1002/eji.201141717

117. Tiemessen MM, Jagger AL, Evans HG, van Herwijnen MJC, John S, Taams LS. CD4+CD25+Foxp3+ regulatory T cells induce alternative activation of human monocytes/macrophages. Proc Natl Acad Sci USA. (2007) 104:1944651. doi: $10.1073 /$ pnas. 0706832104

118. Ehrchen J, Steinmüller L, Barczyk K, Tenbrock K, Nacken W, Eisenacher $\mathrm{M}$, et al. Glucocorticoids induce differentiation of a specifically activated, anti-inflammatory subtype of human monocytes. Blood. (2007) 109:1265-74. doi: 10.1182/blood-2006-02-001115

119. Mosser DM, Edwards JP. Exploring the full spectrum of macrophage activation. Nat Rev Immunol. (2008) 8:958-69. doi: 10.1038/nri2448

120. Zigmond E, Bernshtein B, Friedlander G, Walker CR, Yona S, Kim K-W, et al. Macrophage-restricted interleukin-10 receptor deficiency, but not IL-10 deficiency, causes severe spontaneous colitis. Immunity. (2014) 40:720-33. doi: 10.1016/j.immuni.2014.03.012

121. Liu G, Ma H, Qiu L, Li L, Cao Y, Ma J, et al. Phenotypic and functional switch of macrophages induced by regulatory CD4+CD25+ T cells in mice. Immunol Cell Biol. (2011) 89:130-42. doi: 10.1038/icb.2010.70

122. Mahajan D, Wang Y, Qin X, Wang Y, Zheng G, Wang YM, et al. $\mathrm{CD} 4+\mathrm{CD} 25+$ regulatory $\mathrm{T}$ cells protect against injury in an innate murine model of chronic kidney disease. J Am Soc Nephrol. (2006) 17:2731-41. doi: 10.1681/ASN.2005080842

123. Proto JD, Doran AC, Gusarova G, Yurdagul A, Sozen E, Subramanian $\mathrm{M}$, et al. Regulatory $\mathrm{T}$ cells promote macrophage efferocytosis during inflammation resolution. Immunity. (2018) 49:666-77.e6. doi: 10.1016/j.immuni.2018.07.015

124. Miwa N, Hayakawa S, Miyazaki S, Myojo S, Sasaki Y, Sakai M, et al. IDO expression on decidual and peripheral blood dendritic cells and monocytes/macrophages after treatment with CTLA-4 or interferon-gamma increase in normal pregnancy but decrease in spontaneous abortion. Mol Hum Reprod. (2005) 11:865-70. doi: 10.1093/molehr/gah246

125. Venet F, Pachot A, Debard A-L, Bohe J, Bienvenu J, Lepape A, et al. Human CD4+CD25+ regulatory T lymphocytes inhibit lipopolysaccharideinduced monocyte survival through a Fas/Fas ligand-dependent mechanism. J Immunol. (2006) 177:6540-7. doi: 10.4049/jimmunol.177.9.6540

126. Savage NDL, de Boer T, Walburg KV, Joosten SA, van Meijgaarden K, Geluk A, et al. Human anti-inflammatory macrophages induce Foxp3+ GITR+ $\mathrm{CD} 25+$ regulatory $\mathrm{T}$ cells, which suppress via membrane-bound TGFbeta-1. J Immunol. (2008) 181:2220-6. doi: 10.4049/jimmunol.181.3.2220

127. Alard P, Clark SL, Kosiewicz MM. Mechanisms of tolerance induced by TGF beta-treated APC: CD4 regulatory T cells prevent the induction of the immune response possibly through a mechanism involving TGF beta. Eur J Immunol. (2004) 34:1021-30. doi: 10.1002/eji.200324547

128. Schnoeller C, Rausch S, Pillai S, Avagyan A, Wittig BM, Loddenkemper C, et al. A helminth immunomodulator reduces allergic and inflammatory responses by induction of IL-10-producing macrophages. I Immunol. (2008) 180:4265-72. doi: 10.4049/jimmunol.180.6.4265

129. Parsa R, Andresen P, Gillett A, Mia S, Zhang X-M, Mayans S, et al. Adoptive transfer of immunomodulatory M2 macrophages prevents type 1 diabetes in NOD mice. Diabetes. (2012) 61:2881-92. doi: 10.2337/db11-1635

130. Kraaij MD, Savage NDL, van der Kooij SW, Koekkoek K, Wang J, van den Berg JM, et al. Induction of regulatory T cells by macrophages is dependent on production of reactive oxygen species. Proc Natl Acad Sci USA. (2010) 107:17686-91. doi: 10.1073/pnas.1012016107

131. Hultqvist M, Olofsson P, Holmberg J, Bäckström BT, Tordsson J, Holmdahl R. Enhanced autoimmunity, arthritis, and encephalomyelitis in mice with a reduced oxidative burst due to a mutation in the Ncf1 gene. Proc Natl Acad Sci USA. (2004) 101:12646-51. doi: 10.1073/pnas.0403831101

132. Nathan C. Neutrophils and immunity: challenges and opportunities. Nat Rev Immunol. (2006) 6:173-82. doi: 10.1038/nri1785

133. Deng Q, Harvie EA, Huttenlocher A. Distinct signalling mechanisms mediate neutrophil attraction to bacterial infection and tissue injury. Cell Microbiol. (2012) 14:517-28. doi: 10.1111/j.1462-5822.2011. 01738.x

134. Liu Z, Petersen R, Devireddy L. Impaired neutrophil function in $24 \mathrm{p} 3$ null mice contributes to enhanced susceptibility to bacterial infections. $J$ Immunol. (2013) 190:4692-706. doi: 10.4049/jimmunol.1202411

135. Mantovani A, Cassatella MA, Costantini C, Jaillon S. Neutrophils in the activation and regulation of innate and adaptive immunity. Nat Rev Immunol. (2011) 11:519-31. doi: 10.1038/nri3024

136. Mócsai A. Diverse novel functions of neutrophils in immunity, inflammation, and beyond. J Exp Med. (2013) 210:1283-99. doi: $10.1084 /$ jem. 20122220

137. Fridlender ZG, Sun J, Kim S, Kapoor V, Cheng G, Ling L, et al. Polarization of tumor-associated neutrophil phenotype by TGF-beta: "N1" versus "N2" TAN. Cancer Cell. (2009) 16:183-94. doi: 10.1016/j.ccr.2009.06.017

138. Schmielau J, Finn OJ. Activated granulocytes and granulocyte-derived hydrogen peroxide are the underlying mechanism of suppression of $t-$ cell function in advanced cancer patients. Cancer Res. (2001) 61:4756-60. doi: $10.61 / 12 / 4756$

139. Pillay J, Kamp VM, van Hoffen E, Visser T, Tak T, Lammers J$\mathrm{W}$, et al. A subset of neutrophils in human systemic inflammation inhibits T cell responses through Mac-1. J Clin Invest. (2012) 122:327-36. doi: $10.1172 /$ JCI57990

140. Bowers NL, Helton ES, Huijbregts RPH, Goepfert PA, Heath SL, Hel Z. Immune suppression by neutrophils in HIV-1 Infection: role of PD-L1/PD-1 pathway. PLoS Pathog. (2014) 10:e1003993. doi: 10.1371/journal.ppat.1003993

141. Doz E, Lombard R, Carreras F, Buzoni-Gatel D, Winter N. Mycobacteriainfected dendritic cells attract neutrophils that produce IL-10 and specifically shut down Th17 CD4 T cells through their IL-10 receptor. J Immunol. (2013) 191:3818-26. doi: 10.4049/jimmunol.1300527

142. Zhang X, Majlessi L, Deriaud E, Leclerc C, Lo-Man R. Coactivation of Syk kinase and MyD88 adaptor protein pathways by bacteria promotes regulatory properties of neutrophils. Immunity. (2009) 31:761-71. doi: 10.1016/j.immuni.2009.09.016 
143. Himmel ME, Crome SQ, Ivison S, Piccirillo C, Steiner TS, Levings MK. Human CD4+ FOXP3 + regulatory $\mathrm{T}$ cells produce CXCL8 and recruit neutrophils. Eur J Immunol. (2011) 41:306-12. doi: 10.1002/eji.201040459

144. Lewkowicz N, Klink M, Mycko MP, Lewkowicz P. Neutrophil$\mathrm{CD} 4+\mathrm{CD} 25+\mathrm{T}$ regulatory cell interactions: a possible new mechanism of infectious tolerance. Immunobiology. (2013) 218:455-64. doi: 10.1016/j.imbio.2012.05.029

145. Brooks CJ, King WJ, Radford DJ, Adu D, McGrath M, Savage CO. IL-1 beta production by human polymorphonuclear leucocytes stimulated by antineutrophil cytoplasmic autoantibodies: relevance to systemic vasculitis. Clin Exp Immunol. (1996) 106:273-9.

146. Edwards SW, Hallett MB. Seeing the wood for the trees: the forgotten role of neutrophils in rheumatoid arthritis. Immunol Today. (1997) 18:320-4.

147. Lande R, Ganguly D, Facchinetti V, Frasca L, Conrad C, Gregorio J, et al. Neutrophils activate plasmacytoid dendritic cells by releasing self-DNApeptide complexes in systemic lupus erythematosus. Sci Transl Med. (2011) 3:73ra19. doi: 10.1126/scitranslmed.3001180

148. Brusko TM, Putnam AL, Bluestone JA. Human regulatory T cells: role in autoimmune disease and therapeutic opportunities. Immunol Rev. (2008) 223:371-90. doi: 10.1111/j.1600-065X.2008.00637.x

149. Richards H, Williams A, Jones E, Hindley J, Godkin A, Simon AK, et al. Novel role of regulatory $\mathrm{T}$ cells in limiting early neutrophil responses in skin. Immunology. (2010) 131:583-92. doi: 10.1111/j.1365-2567.2010. 03333.x

150. Okeke EB, Mou Z, Onyilagha N, Jia P, Gounni AS, Uzonna JE. Deficiency of phosphatidylinositol 3-kinase $\delta$ signaling leads to diminished numbers of regulatory $\mathrm{T}$ Cells And Increased Neutrophil Activity Resulting In Mortality Due To Endotoxic Shock. J Immunol. (2017) 199:1086-95. doi: 10.4049/jimmunol.1600954

151. Lewkowicz P, Lewkowicz N, Sasiak A, Tchórzewski H. Lipopolysaccharideactivated $\mathrm{CD} 4+\mathrm{CD} 25+\mathrm{T}$ regulatory cells inhibit neutrophil function and promote their apoptosis and death. J Immunol. (2006) 177:7155-63. doi: 10.4049/jimmunol.177.10.7155

152. Born WK, O'Brien RL. Discovery of the $\gamma \delta$ TCR: Act II. J Immunol. (2016) 196:3507-8. doi: 10.4049/jimmunol.1600404

153. Tanaka Y, Morita CT, Tanaka Y, Nieves E, Brenner MB, Bloom BR. Natural and synthetic non-peptide antigens recognized by human $\gamma \delta$ T cells. Nature. (1995) 375:155-8. doi: 10.1038/375155a0

154. Wu Y, Wu W, Wong WM, Ward E, Thrasher AJ, Goldblatt $\mathrm{D}$, et al. Human gamma delta $\mathrm{T}$ cells: a lymphoid lineage cell capable of professional phagocytosis. J Immunol. (2009) 183:5622-9. doi: 10.4049/jimmunol.0901772

155. Nanno $M$, Shiohara $T$, Yamamoto $H$, Kawakami $K$, Ishikawa $H$. gammadelta $\mathrm{T}$ cells: firefighters or fire boosters in the front lines of inflammatory responses. Immunol Rev. (2007) 215:103-13. doi: 10.1111/j.1600-065X.2006.00474.x

156. Wu Y-L, Ding Y-P, Tanaka Y, Shen L-W, Wei C-H, Minato N, et al. $\gamma \delta \mathrm{T}$ cells and their potential for immunotherapy. Int J Biol Sci. (2014) 10:119-35. doi: 10.7150/ijbs.7823

157. Pauza CD, Liou M-L, Lahusen T, Xiao L, Lapidus RG, Cairo C, et al. Gamma delta T cell therapy for cancer: it is good to be local. Front Immunol. (2018) 9:1305. doi: 10.3389/fimmu.2018.01305

158. Ribot JC, Chaves-Ferreira M, d'Orey F, Wencker M, Goncalves-Sousa $\mathrm{N}$, Decalf J, et al. Cutting edge: adaptive versus innate receptor signals selectively control the pool sizes of murine IFN- - or IL-17-producing T cells upon infection. J Immunol. (2010) 185:6421-5. doi: 10.4049/jimmunol. 1002283

159. Shibata K, Yamada H, Nakamura M, Hatano S, Katsuragi Y, Kominami $\mathrm{R}$, et al. IFN- $\gamma$-producing and IL-17-producing $\gamma \delta \mathrm{T}$ cells differentiate at distinct developmental stages in murine fetal thymus. J Immunol. (2014) 192:2210-8. doi: 10.4049/jimmunol.1302145

160. Korn T, Petermann F. Development and function of interleukin 17-producing $\gamma \delta \mathrm{T}$ cells. Ann N Y Acad Sci. (2012) 1247:34-45. doi: 10.1111/j.1749-6632.2011.06355.x

161. Papotto PH, Reinhardt A, Prinz I, Silva-Santos B. Innately versatile: $\gamma \delta 17 \mathrm{~T}$ cells in inflammatory and autoimmune diseases. J Autoimmun. (2018) 87:2637. doi: 10.1016/J.JAUT.2017.11.006

162. Wohler JE, Smith SS, Zinn KR, Bullard DC, Barnum SR. Gammadelta T cells in EAE: early trafficking events and cytokine requirements. Eur J Immunol. (2009) 39:1516-26. doi: 10.1002/eji.200839176
163. Malik S, Want MY, Awasthi A. The emerging roles of gamma-delta T cells in tissue inflammation in experimental autoimmune encephalomyelitis. Front Immunol. (2016) 7:14. doi: 10.3389/fimmu.2016.00014

164. Ito Y, Usui T, Kobayashi S, Iguchi-Hashimoto M, Ito H, Yoshitomi H, et al. Gamma/delta T cells are the predominant source of interleukin-17 in affected joints in collagen-induced arthritis, but not in rheumatoid arthritis. Arthritis Rheum. (2009) 60:2294-303. doi: 10.1002/art.24687

165. Kang N, Tang L, Li X, Wu D, Li W, Chen X, et al. Identification and characterization of Foxp3(+) gammadelta $\mathrm{T}$ cells in mouse and human. Immunol Lett. (2009) 125:105-13. doi: 10.1016/j.imlet.2009.06.005

166. Casetti R, Agrati C, Wallace M, Sacchi A, Martini F, Martino A, et al. Cutting edge: TGF-beta1 and IL-15 induce FOXP3+ gammadelta regulatory T cells in the presence of antigen stimulation. J Immunol. (2009) 183:3574-7. doi: 10.4049/jimmunol.0901334

167. Seo N, Tokura Y, Takigawa M, Egawa K. Depletion of IL-10- and TGF-betaproducing regulatory gamma delta $\mathrm{T}$ cells by administering a daunomycinconjugated specific monoclonal antibody in early tumor lesions augments the activity of CTLs and NK cells. J Immunol. (1999) 163:242-9.

168. Rhodes KA, Andrew EM, Newton DJ, Tramonti D, Carding SR. A subset of IL-10-producing $\gamma \delta \mathrm{T}$ cells protect the liver from Listeria elicited, CD8 ${ }^{+}$T cell-mediated injury. Eur J Immunol. (2008) 38:2274-83. doi: 10.1002/eji.200838354

169. Park S-G, Mathur R, Long M, Hosh N, Hao L, Hayden MS, et al. T regulatory cells maintain intestinal homeostasis by suppressing $\gamma \delta \mathrm{T}$ cells. Immunity. (2010) 33:791-803. doi: 10.1016/j.immuni.2010.10.014

170. Yurchenko E, Levings MK, Piccirillo CA. CD4+ Foxp3+ regulatory $\mathrm{T}$ cells suppress $\gamma \delta \mathrm{T}$-cell effector functions in a model of T-cellinduced mucosal inflammation. Eur J Immunol. (2011) 41:3455-66. doi: 10.1002/eji.201141814

171. Li L, Wu C-Y. CD4+ CD25+ Treg cells inhibit human memory gammadelta $\mathrm{T}$ cells to produce IFN-gamma in response to $\mathrm{M}$ tuberculosis antigen ESAT-6. Blood. (2008) 111:5629-36. doi: 10.1182/blood-2008-02-139899

172. Xu D, Robinson AP, Ishii T, Duncan DS, Alden TD, Goings GE, et al. Peripherally derived T regulatory and $\gamma \delta \mathrm{T}$ cells have opposing roles in the pathogenesis of intractable pediatric epilepsy. J Exp Med. (2018) 215:116986. doi: 10.1084/jem.20171285

173. Pedroza-Pacheco I, Madrigal A, Saudemont A. Interaction between natural killer cells and regulatory T cells: perspectives for immunotherapy. Cell $\mathrm{Mol}$ Immunol. (2013) 10:222-9. doi: 10.1038/cmi.2013.2

174. Aron JL, Akbari O. Regulatory T cells and type 2 innate lymphoid celldependent asthma. Allergy. (2017) 72:1148-55. doi: 10.1111/all.13139

175. Tang Q, Bluestone JA. The Foxp3+ regulatory T cell: a jack of all trades, master of regulation. Nat Immunol. (2008) 9:239-44. doi: 10.1038/ni1572

176. Gu P, Gao JF, D’Souza CA, Kowalczyk A, Chou K-Y, Zhang L. Trogocytosis of CD80 and CD86 by induced regulatory T cells. Cell Mol Immunol. (2012) 9:136-46. doi: 10.1038/cmi.2011.62

177. Wing K, Onishi Y, Prieto-Martin P, Yamaguchi T, Miyara M, Fehervari Z, et al. CTLA-4 control over Foxp3 + regulatory T cell function. Science. (2008) 322:271-5. doi: 10.1126/science.1160062

178. Walker LSK. Treg and CTLA-4: two intertwining pathways to immune tolerance. J Autoimmun. (2013) 45:49-57. doi: 10.1016/j.jaut.2013.06.006

179. Qureshi OS, Zheng Y, Nakamura K, Attridge K, Manzotti C, Schmidt EM, et al. Trans-endocytosis of CD80 and CD86: a molecular basis for the cell-extrinsic function of CTLA-4. Science. (2011) 332:600-3. doi: 10.1126/science. 1202947

180. Hou TZ, Qureshi OS, Wang CJ, Baker J, Young SP, Walker LSK, et al. A transendocytosis model of CTLA-4 function predicts its suppressive behavior on regulatory T cells. J Immunol. (2015) 194:2148-59. doi: $10.4049 /$ jimmunol.1401876

Conflict of Interest Statement: The authors declare that the research was conducted in the absence of any commercial or financial relationships that could be construed as a potential conflict of interest.

Copyright (c) 2019 Okeke and Uzonna. This is an open-access article distributed under the terms of the Creative Commons Attribution License (CC BY). The use, distribution or reproduction in other forums is permitted, provided the original author(s) and the copyright owner(s) are credited and that the original publication in this journal is cited, in accordance with accepted academic practice. No use, distribution or reproduction is permitted which does not comply with these terms. 